\title{
ARTIGOS
}

\section{EFFECTS OF LEVAMISOLE ON EXPERIMENTAL INFECTIONS BY PLASMODIUM BERGHEI IN MICE}

\author{
Enrique Melendez C.1 e Antoniana U. Krettli ${ }^{2}$
}

\begin{abstract}
Levamisole (phenylimidothiazol), considered a strong immunostimulant, when administered to healthy Swiss mice did not cause a significant increase in the weight of their thymus, liver and spleen, even though the drug was used at different times before removing such organs. High doses of drug used in the 4-day prophylactic scheme had no antimalarial effect. However, when given to malaria infected mice 24 hours before, at the same time, and 24 hours after the inoculation of a chloroquine-sensitive or a chloroquine-resistant strain of Plasmodium berghei small doses of the drug induced a somewhat decreased parasitemia, the dose of $1 \mathrm{mg} / \mathrm{kg}$ body weight before the inoculum being the best scheme. The mortality rates by malaria in the levamisole treated groups were also delayed although all mice finally died. The data suggest that levamisole may display a stimulant effect on the depressed immune response caused by malaria.
\end{abstract}

Key words: Malaria. Plasmodium berghei. Chloroquine-resistant strain. Levamisole. Immunostimulation.

Malaria induced by $P$. berghei in rodents or by other plasmodia, including those in human species, decreases the immune response of infected vertebrates against unrelated antigens and causes an increased susceptibility to concomitant infections (Review in 6). Experimental studies have demonstrated a reduction in the B lymphocytes and the total number of cells in peripheral lymph nodes of mice infected with $P$. berghei as well as a substancial decrease of thymus weight and rates of thymus $\mathrm{T}$ cells ${ }^{7}$. Furthermore, a decreased number of circulating lymphocytes in children with malaria has been observed ${ }^{313}$. A progressive infiltration of plasma cells in periarteriolar areas of the spleen of infected mice was shown during the immunosupression period ${ }^{9}$. Recent studies also show that the lymphocyte response to purified Plasmodium falciparum antigen during acute malaria caused by this parasite is significantly reduced. However, the response to other unrelated mitogens (lectins) or to tuberculin antigen was not suppressed by malaria ${ }^{1}$. Some drugs and biological agents have been used as immu-

1. Sección de Parasitologia, Escuela de Medicina, Univerdad Centro Occidental "Lisandro Alvarado", Apartado 400 , Barquisimeto, Venezuela.

2. Departamento de Parasitologia, ICB, Universidade Federal de Minas Gerais and Centro de Pesquisas René Rachou, FIOCRUZ, Belo Horizonte, MG, Brasil.

Reprint requests to A.U. Krettli. Av. Augusto de Lima 1715. 30190 Belo Horizonte, MG, Brazil.

Part of this work was presented at the Congress of Parasitology, Equador, 1985. Work supported by CNPqBrazil.

Recebido para publicação em 3/11/86. nostimulants, such as cyclophosphamide, which may give the animal some protection against malaria ${ }^{2}$.

Levamisole is also considered an immunopotentiating agent although the drug was originally used for its therapeutic value against helminths (filarias) and some protozoal infections (leishmaniasis) (Review in 11). The improvement of the immune functions by the drug has been attributed to the enhancement of cell activity and to an increased number of total $T$ cells when they were depleted. Since the effectiveness of many prophylactic and therapeutic drugs can be increased by the host immune response ${ }^{11}$ and since malaria is immunosuppressive, we have investigated the immunopotentiating activity of levamisole in malaria. In parallel, we have also determined a possible change in the total weight of the thymus, spleen and liver, organs involved in the immune response, after treatment of normal mice with levamisole.

\section{MATERIAL AND METHODS}

Parasites - Parasites of the erythrocytic cycle of $P$. berghei NK65 ${ }^{14}$ sensitive to chloroquine, and, a chloroquine-resistant strain (CR) were maintained by weekly blood passages in female Swiss mice with 18 to 20 grams weight and a standard inoculum. The CR strain was drug-induced in the laboratory ${ }^{5}$ and frozen at $-7^{\circ} \mathrm{C}$ for 6 years before use. It was then kept in mice under chloroquine action to maintain its resistance to the drug.

Inoculation with $P$. berghei - Infected blood was collected in $3.8 \%$ sodium citrate solution from the orbital sinus of mice at the peak parasitemia. The percentage of infected cells was determined in Giemsa 
stained blood smears and the total number of red blood cells (RBC) in a Neubauer chamber. After the desired dilution in sodium citrate $10^{7}$ parasitized RBC were given to each animal by intraperitoneal route (i.p.). Parasitemia was determined by blood smears every 48 hours until the animal death. Mortality was daily monitored.

Administration of levamisole - Levamisole hydrochloride, a imidothiazolic derivate kindly provided by Johnson \& Johnson Laboratories (Campinas, São Paulo), was dissolved in distilled water to give $0.25 \mathrm{ml}$ per mice p.o. Groups of 6 or 7 animals inoculated with $P$. berghei received levamisole in the doses of $0.1,1$ or $10 \mathrm{mg} / \mathrm{kg}$ of body weight, either as a single dose or on 2 consecutive days according to the following scheme: a) 24 hours before the inoculum; b) concomitant to the inoculum; c) 24 hours after inoculation. The two criteria used to evaluate the immunostimulant effect of the drug were parasitemia curves and mortality in both control untreated and experimental groups.

With the $P$. berghei CR strain a dosage of $1 \mathrm{mg} / \mathrm{kg}$ per 1 or 2 consecutive days before the inoculum was used.

Liver, spleen, and thymus weight after levamisole - Groups of 3 or 4 treated or untreated normal mice were used to evaluate the effect of levamisole on the weight of the lymphoid organs; $0.1,1$ or $10 \mathrm{mg} / \mathrm{kg}$ were used in either a single dose or on 2 consecutive days. Animals were sacrificed at 24, 48 and 72 hours after the drug administration according to each scheme. Each animal was anesthetized with sulfuric ether and total bleeding was done sectioning the vascular axilar plexus. Then their spleens, livers and thymuses were carefully removed and immediately weighed on a Mettler precision balance (Mo-H31 AR).

Chemotherapeutic activity of levamisole against $P$. berghe $i$ - To determine a possible chemotherapeutic activity of levamisole, groups of 7 mice inoculated i.p. with $10^{7} P$. berghei parasitized $\mathrm{RBC}$ were treated with 4 consecutive daily doses of 25,50 , 100 and $150 \mathrm{mg} / \mathrm{kg}$. Blood smears were examined on the $5^{\text {th }}$ and 7 th days after inoculation, in both control and treated groups, to determine the rate of parasitemia. Mortality was daily monitored.

Statistic analysis - Student's " $t$ " test was used to determine the significance of the differences among the means in the liver, spleen and thymus weights; a $\mathrm{X}^{2}$ test was used to determine the significance of the differences among parasitemia means.

\section{RESULTS}

Therapeutic activity of levamisole - There was no differences in parasitemia by $P$. berghei in levamisole treated or untreated groups (Fig. 1). Mortality

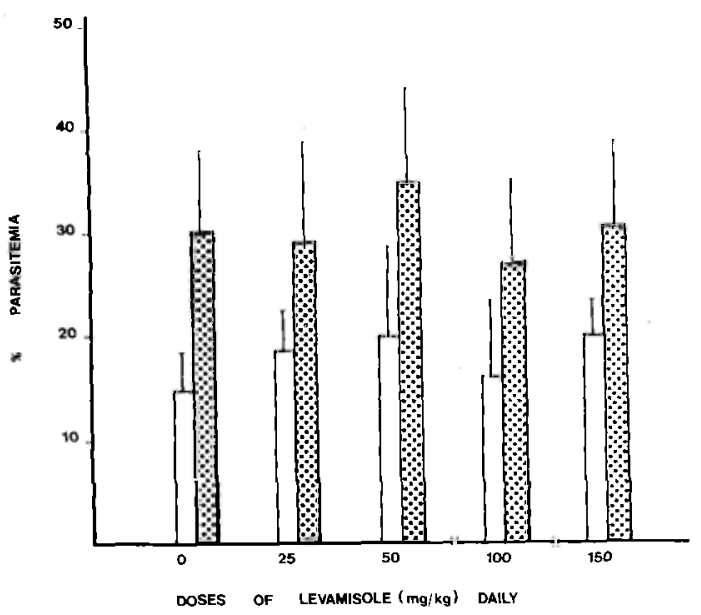

Figure 1-Parasitemia rates in mice on days $5(\square)$ and $7(\square)$ after i.p. inoculation with Plasmodium berghei ( $10^{7}$ infected RBC per mouse) and treatment, by oral route, with different doses of levamisole, during 4 consecutive days, beginning 24 hours after parasite inoculation. Vertical lines indicate the standard error of the mean $(n=6)$. There was no statistical difference between parasitemia in control and treated groups.

rates of $100 \%$ were observed on all groups by day 10 after inoculation. Therefore, levamisole was ineffective against $P$. berghei.

Levamisole effect on lymphoid organs of normal mice - When either a single dose of levamisole or two of $0.1,1$ or $10 \mathrm{mg} / \mathrm{kg}$ were given to normal mice their thymus and spleen weights were in general above the normal values although only with the higher dose of drug, given 48 or 72 hours before, this increased size was more clearly detected. However, the differences were not statistically significant on either the liver, spleen or thymus weights during the treatment(Fig. 2). Since there were rather large individual variations with some of the animals this might have affected the mean of the groups.

Immunostimulant effect of levamisole on infections by $P$. berghei - Levamisole did not alter the course of infection by $P$. berghei when administered in different doses at the same time or after the inoculum. However, when levamisole was administered 24 hours before the infection by $P$. berghei parasitemia means were reduced from day 4 on, in relation to the control groups using the doses of 1 or $10 \mathrm{mg} / \mathrm{kg}$ (Fig. 3). Furthermore, when levamisole was administered with the doses of $0.1,1$ or $10 \mathrm{mg} / \mathrm{kg}$, for two consecutive days before inoculation, but specially at the dose of $1 \mathrm{mg} / \mathrm{kg}$, mean parasitemia were clearly reduced in relation to the control group (Fig. 4). The mortality rates were somewhat delayed after levamisole treatment of malaria infected mice in these cases. 


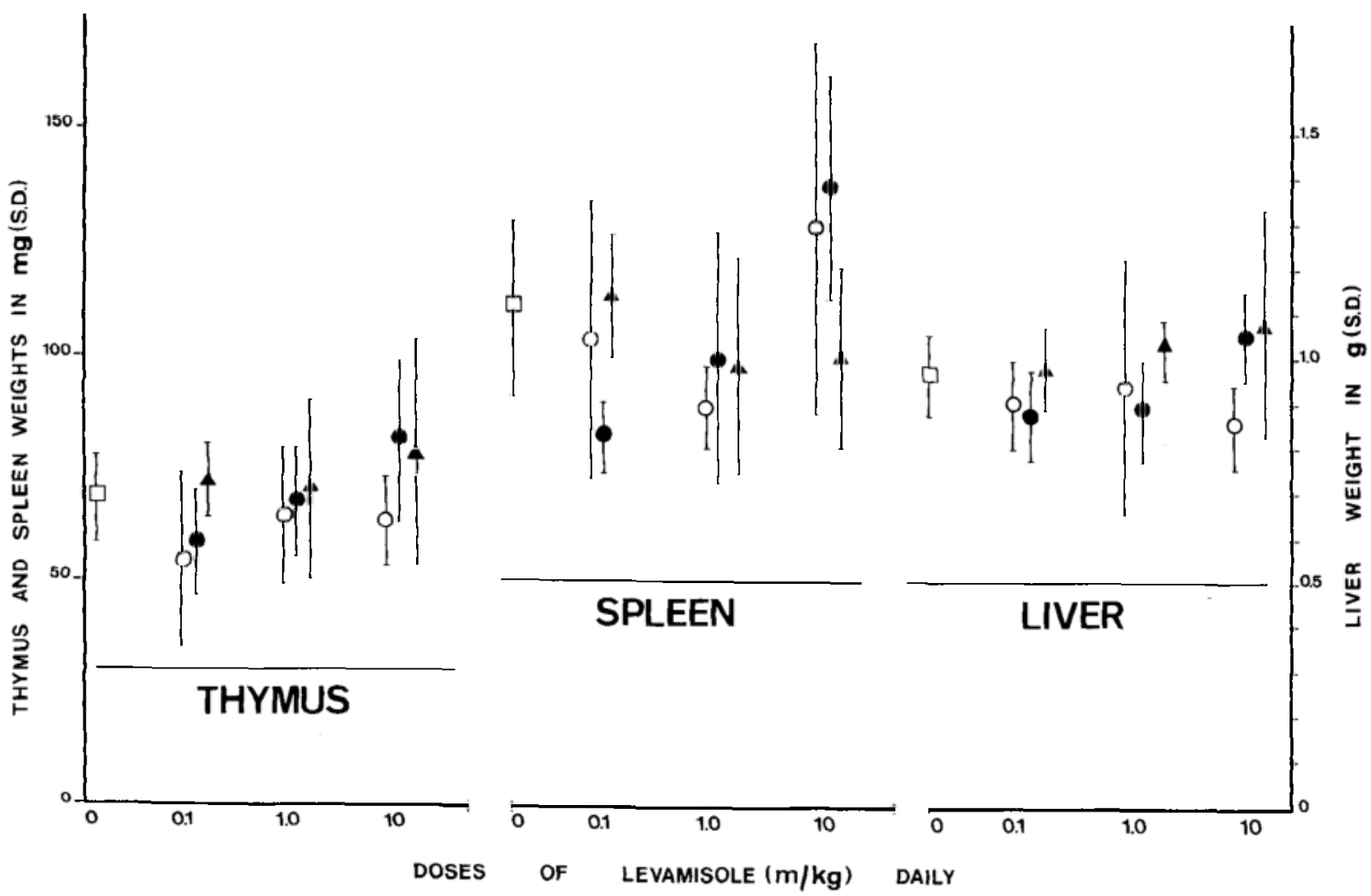

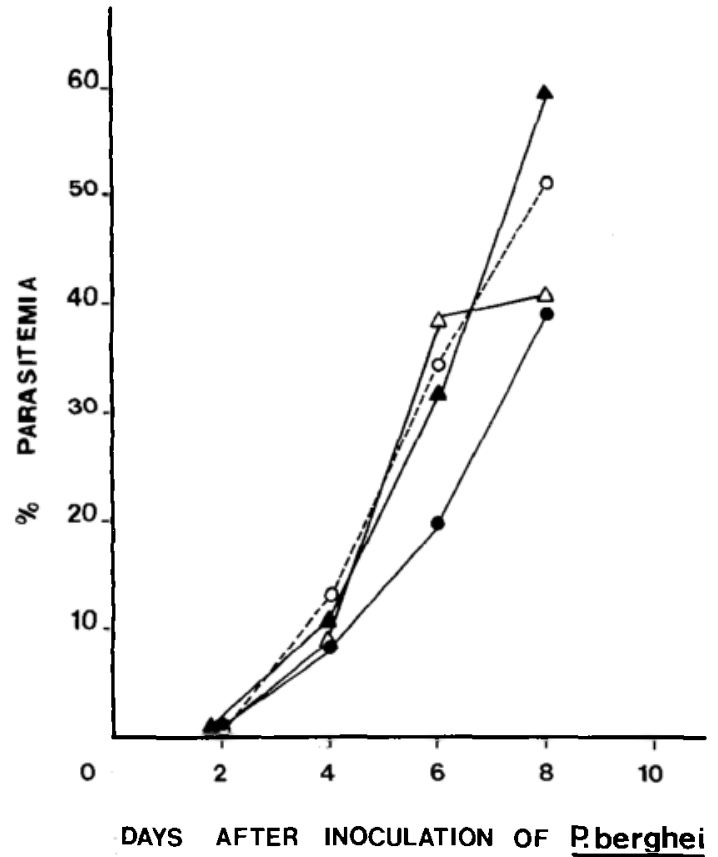

Figure 3 - Mean parasitemia by Plasmodium berghei (strain NK65) in groups of mice inoculated by intraperitoneal route with $10^{7}$ parasitized RBC. In solid lines are the groups treated with different doses $(\mathrm{mg} / \mathrm{kg})$ of levamisole $(\Theta=0.1 ; \Delta=1.0 ; \Delta=10)$ given once 24 hours before inoculation and in dotted line the untreated mice.
Figure 2 - Means and standard deviations of thymus, liver and spleen weights of normal untreated mice ( $\square$ ) or mice previously treated with levamisole by oral route in different doses, given $24(0), 48(0)$ or 72 hours (A) before, in two consecutive days. There was no statistical difference between control and treated mice.

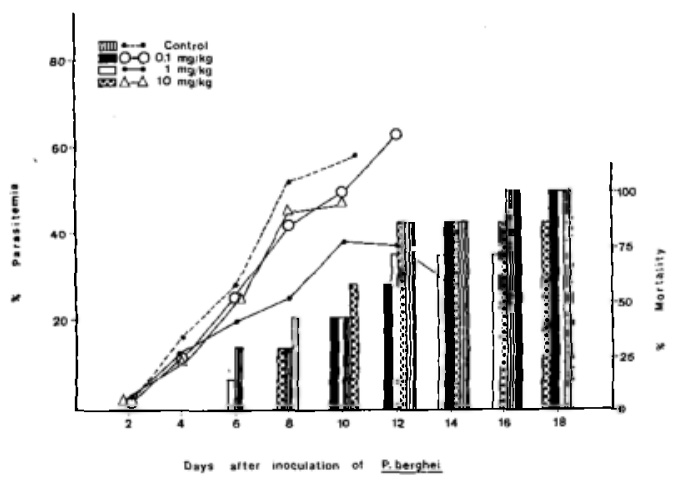

Figure 4 - Mean parasitemia and cumulative mortality rates by Plasmodium berghei in mice inoculated with $10^{7}$ parasitized $\mathrm{RBC}$ by intraperitoneal route. Control untreated group (dotted line) or groups treated by oral route with different doses of levamisole $(\mathrm{mg} / \mathrm{kg})(\odot=0.1 ; \Delta=1.0 ; \Delta=10.0)$ given twice, at 48 and 24 hours before parasite inoculation. 
Melendez H, Krettli A. Effects of levamisole on experimental infections by Plasmodium berghei in mice. Revista da Sociedade Brasileira de Medicina Tropical 20: 193-198, Out-Dez, 1987

Effect of levamisole on a chloroquine-resistant (CR) P. berghei strain-A reduction in the parasitemia was found after administering levamisole at $1 \mathrm{mg} / \mathrm{kg}$ dose, the only dose used, before the infection by CR $P$. berghei strain. Parasitemia was also reduced in other groups treated with either chloroquine alone or levamisole plus chloroquine. There was no significant reduction in the mortality rates in the experimental groups although they were delayed by levamisole treatment.

\section{DISCUSSION}

In the present work we show that levamisole is not active against $P$. berghei even though doses close to the toxic levels have been used. The thymus and spleen weights were increased by the drug used in normal mice $(1-10 \mathrm{mg} / \mathrm{kg})$ but the statistical analysis show no significant difference in relation to untreated mice. The later result has also been observed by Hoebeke and Franchi ${ }^{4}$ though in their experiments they worked with animals ranging from 20 to $25 \mathrm{~g}$ of weight. The weight variation in our mice ranged from 18 to $20 \mathrm{~g}$ allowing therefore a more precise evaluation of the organ weights.

When levamisole was administered before the inoculation of $P$. berghei strain NK65, the drug produced a reduction of parasitemia which was more pronounced between the $4^{\text {th }}$ and $8^{\text {th }}$ day of infection, and using $1 \mathrm{mg} / \mathrm{kg}$ dose for two consecutive days. Thus it was apparently this dose which better stimulated the immunity in the infected animals. The decreased parasitemia observed after levamisole treatment may have been a result of an increased phagocytosis with destruction of the plasmodia. Some authors have proved that this drug causes a significant stimulation of RBC phagocytosis ${ }^{4}$.

After the $8^{\text {th }}$ day of $P$. berghei inoculation levamisole did not alter parasitemia possibly because its highest immunostimulant effect was present during the first 48 hours after drug administration ${ }^{10}$. Indeed, levamisole administered at the same time or after inoculation of parasites, did not alter the parasitemias, as reported by other authors 12 .

Based on our results and because levamisole is a already used in humans we suggest that levamisole could be used in human malaria in careful studies, initially with $P$. vivax, since this parasite is not usually lethal. It may improve treatment of the disease by chloroquine and eventually help the difficult task of controlling malaria parasitemias in the $P$. falciparum $C R$ strains, now largely spread in all endemic areas in Brazil.

\section{RESUMO}

Levamisol (fenilimidotiazol), considerado um potente imunoestimulante, quando administrado a camundongos suífos não causou aumento significan- te nos pesos do timo, figado ou baço, apesar de a droga ter sido usada em diferentes tempos antes da remoção desses orgãos. Doses elevadas da droga usadas no esquema profilático de 4 dias não tiveram efeito antimalárico. Entretanto quando dada a camundongos com malaria, 24 horas antes, ao mesmo tempo ou 24 horas após inoculação de uma cepa de Plasmodium berghei cloroquina-sensivel ou uma cepa cloroquinaresistente o levamisol reduziu, ainda que discretamente, a parasitemia nos grupos tratados, sendo a dose de $1 \mathrm{mg} / \mathrm{kg}$ o melhor esquema. Foi observado também atraso na mortalidade por malaria nos grupos tratados com o levamisol. No entanto, todos os animais morreram. Os dados sugerem que o levamisol tem efeito imunoestimulante, ainda que discreto, na resposta imune de animais, deprimida pela malaria.

Palavras chaves: Malária. Plasmodium berghei. Cepa cloroquina-resistente. Levamisol. Imunoestimulante.

\section{ACKNOWLEDGEMENTS}

We acknowledge the assistance of Argenis Perozo and Robert Smith with the manuscript and CNPq-Brazil for financial support.

\section{REFERENCES}

1. Bygbjer IC, Jepsen S, Theander TG. Lymphocyte response to purified Plasmodium falciparum antigens during and after malaria. Acta Tropica 43: 55-62, 1986.

2. Finerty JF, Krehl EP. Cyclophosphamide pretreatment and protection against malaria. Infection and Immunity 14: 1103-1105, 1976.

3. Greenwood BM, Odulaju AJ, Straton D. Lymphocyte changes in acute malaria. Transactions of the Royal Society of Tropical Medicine and Hygiene 71: 408-410, 1977.

4. Hoebeke J, Franchi G. Influence of tetramisole and its optical isomers on the mononuclear phagocytic system. Journal of Reticuloendothelial Society 14: 317-323, 1973.

5. Krettli AU, Brener Z. Therapeutic activity of some sulfonamide compounds on normal and chloroquine-resistant strains of Plasmodium berghei. Revista do Instituto de Medicina Tropical de São Paulo 10: 389-393, 1968.

6. Krettli AU, Lima-Pereira FE. Immunosuppression in protozoal infections. In: Levandowsky $\mathbf{M}$, Hunter SH (eds.) Biochemistry and Physiology of Protozoa 4: 431458, Academic Press, New York, 1981.

7. Krettli AU, Nussenzweig RS. Depletion of T and B lymphocytes during malarial infections. Cellular Immunology 13: 440-446, 1974.

8. Oliveira-Lima A, Javierre MQ, Silva WD, Càmara DS. Immunological phagocytosis: effect of drugs on phosphodiesterase activity. Experientia 30: 945-946, 1974.

9. Poels LG, Nieckerk CC. Plasmodium berghei: Immunosuppresion and hyperimmunoglobulinemia. Experimental Parasitology 42: 235-247, 1977.

10. Symoens J, Rosenthal M. Levamisole in the modulation 
Melendez $H$, Krettli A. Effects of levamisole on experimental infections by Plasmodium berghei in mice. Revista da Sociedade Brasileira de Medicina Tropical 20: 193-198, Out-Dez, 1987

of the immune response: the current experimental and clinical state. Journal of Reticuloendothelial Society 21: 175-221, 1977.

11. Targett GAT. Chemotherapy and the immune response in parasitic infections. Parasitology 90; 661-673, 1985.

12. Tosta CE, Nicolau F. Possivel efeito do levamisole na malária: aumento específico e inespecífico da fagocitose.
Ciência e Cultura 28: 612, 1976.

13. Wyler DJ. Peripheral lymphocyte subpopulations in human falciparum malaria. Clinical and Experimental Immunology 23: 471-476, 1976.

14. Yoeli M. Studies on $P$. berghei in nature and under experimental conditions. Transactions of the Royal Society of Tropical Medicine and Hygiene 59: 255-276, 1965. 